\title{
A Proposed Conceptual Framework for Market Orientation and Innovation towards Takaful Performance in Malaysia
}

\author{
Norizan Remli ${ }^{1}$, Wan Norhayate Wan Daud ${ }^{1}$, Fakhrul Anwar Zainol ${ }^{1}$ \& Hamizah Muhammad $^{1}$ \\ ${ }^{1}$ Universiti Sultan Zainal Abidin, Gong Badak Campus, Terengganu, Malaysia \\ Correspondence: Wan Norhayate Wan Daud, Universiti Sultan Zainal Abidin, Gong Badak Campus, 21300 \\ Kuala Terengganu, Terengganu, Malaysia. Tel: 609-012-981-8045. E-mail: wnhayate@unisza.edu.my
}

Received: June 17, 2012

Accepted: December 11, 2012

Online Published: March 14, 2013

doi:10.5539/ijbm.v8n7p100

URL: http://dx.doi.org/10.5539/ijbm.v8n7p100

\begin{abstract}
This paper aims to propose a conceptual framework to study the relationship between Market Orientation and Organizational Performance from Takaful Business's standpoint in Malaysia. The Innovation was added in this research to represents the mediating factor. Apparently the framework suggests that Market Orientation has positively effects Performance of the organization. Considering Innovation as the catalyst within the relationship, the mediating effect of it is to be investigated. From the review of literatures, hypotheses were developed to suggest the relationship between the Market Orientation, Innovation and Performance by choosing the Takaful Operators in Malaysia as the research sample. The findings of this research are expected to provide new ideas for the representative specially Marketing Manager from Takaful industry to increase their level of market penetration which is still low at the present.
\end{abstract}

Keywords: market orientation, innovation, performance, Takaful, Malaysia

\section{Introduction}

Organizational performance is the ultimate relevant to scholars to do the management research. Study by Richard, Devinney, Yip, and Johnson (2009) reveals a multidimensional conceptualization of organizational performance. In 1972, Alchian and Demsetz (1972) conceptually viewed performance as the comparison of the value created by a firm with the value owners expected to receive from the firm. Further, Venkatraman and Ramanujam (1986) also define financial and operational performance. At this time, Homburg, Hoyer, and Fassnacht (2002) made a fundamental distinction between nonfinancial and financial performance measures. They defined the nonfinancial company performance is the effective organization's marketing activities and can be evaluated through customer satisfaction, customer loyalty, customer benefit and market share. Meanwhile, financial performance refers to the profitability and can be measured by return on sales, return on investment and return on assets.

Based on the contribution was made to organizational performance, marketing strategies become tremendously beneficial to the organization. Market orientation's relationship is one of the marketing strategy tools towards the organizational performance was largely established by Im and Workman Jr., 2004. Market Orientation was proved connected with the business performance and was widely held to be self-evident until the mid-1980's, when marketing practitioners found that they were increasingly out-marketed by superior performance (Ellis, 2005).

Today, value added of the product is required to be competitively placed in the market. In 1998, Han, Kim and Srivasta articulated that innovation is the missing link between market orientation and organizational performance. Longitudinal study conducted by Huhtala et al., (2010) contributed to the pool of discussion on the role of innovation capability in mediating the effect of market orientation on business performance. Research made by Cheng and Krumwiede (2010) using a component-wise approach confirmed mediating effects of innovation on the market orientation and organizational performance relationship.

Although market orientation creates superior performance in the western economies but in other countries such as developing countries especially, the implementation still leaves some gaps in both the theory and practice of marketing (Sany, Rushami, \& Rozita, 2009). Studies related to market orientation and it is relationship on the organizational performance in the service industry such as insurance and Takaful especially in Malaysia context has been scarce. Thus, the objectives of the study are to identify the relationship between Market Orientation, 
Innovation and Performance of Takaful business in Malaysia. Therefore, this study is structured as follows: First, a summary of literature on the concept of Performance, Market Orientation and Innovation is thoroughly discussed. Second, the proposed conceptual framework is highlighted. Third, the methodology and sample are both described and finally the conclusion is provided by summarizing the avenues for future findings.

\section{Literature Review}

\subsection{Underlying Theory}

Resource-Advantage Theory of Competition (R-A Theory) is chosen as the underlying theory for this study. R-A Theory suggested ten essential criteria that can observe in order to suit the way how it works. They are; (i) it looks demand is varies within industries, (ii) the consumer information is imperfect and costly to be obtained, (iii) human motivation is a constraint by self-interest that is fear of personal effect, (iv) organizations' objective is always superior financial performance, (v) organization's information is imperfect and costly to be obtained, (vi) resources of the organization are mainly financial, physical, legal, human, organizational, informational and relational, (vii) the characteristics of the resources are varies and imperfectly mobile, (viii) the role of management is to recognize, understand, create, select, implement and modify strategies to be applicable to the organization, (ix) the role of the environment in the organization is to influence the conduct and performance of the organization and $(\mathrm{x})$ the competition within the industries is the comparative advantage to the organization (Hunt \& Morgan, 1995).

Generally based on R-A Theory, the consumers' tastes and preferences always change. For that reason, Hunt and Morgan (1995) suggested that the firms which look for superior financial performance, they need to engage major innovations as a new resource to become competitive advantage as compare to the competitors. Within the R-A theory framework, market orientation serves as the intangible resources offered value for market segments to the firm to produce efficiently and/or effectively. The application of this theory will lay the organization to observe and take up market orientation as one of the important strategy in performing their marketing strategy to achieve superior performance.

\subsection{Market Orientation and Organizational Performance Relationship}

Growing from the earlier terms "marketing philosophy" and "marketing concept", Market Orientation had been proved to have a connection with the business (Ellis, 2005). Using a sample of 159 hospitals, Kumar, Subramaniam and Yauger (1998) had proved the existence of a strong relationship between market orientation and various measures of organizational performance. Even though the study focus on the hospitals which consist of profit and non-profit organization, results shows that market orientation affects every aspect of organizational performance in the industry.

In a study of market orientation and company profitability, further evidence incorporating longitudinal data, Dawes (2000) found that the components of a market orientation, competitor orientation emerged the strongest association with performance. Similarly, study by Ellis (2006) also supports the relationship between market orientation and firm performance. In general, firms can improve their performance by encouraging better customer service as compared to their rivals. Reviewing the previous studies on the relationship between market orientation and organizational performance lead to the conclusion of the positive relationship between market orientation and organizational performance is existed.

\subsection{Market Orientation and Innovation Relationship}

Several studies point out that market-driven businesses create products that transform market needs (Lukas \& Ferrel, 2000). Based on a sample of eight hundred (800) US manufacturing companies listed in Dun's Market Identifiers File randomly selected, they investigated the relationship between market orientation and product innovation and the analysis of the study demonstrated that product innovation varies with market orientation. Particularly, 1) customer orientation increases the introduction of new-to-the-world products and reduces the launching of me-too products, 2) competitor orientation increases the introduction of me-too products and reduces the launching of line extensions and new-to-the-world products, and 3) interfunctional coordination increases the launching of line extensions and reduces the introduction of me-too products. Further, Lukas and Ferrel (2000) suggested that businesses seeking to commercialize more breakthrough innovations should focus on a strong customer orientation, businesses desire to match their competitors with comparable products should emphasize on a strong competitor orientation and businesses desire for extending the existing product lines should stress on a strong interfunctional coordination.

According to Hult and Ketchen (2001), innovation consequences include firm innovativeness that is their ability to create and implement new ideas, products and processes (cited in Kirca et. al., 2005). Hurley and Hult 
(1998) suggested that research on market orientation and performance should directly incorporate innovation. The strong empirical connection between organizational innovativeness and innovative capacity found in their study supported this suggestion. They also verify that market orientation as an antecedent to innovativeness. Other researchers were noted the relationship between market orientation and innovation are intuitive. Based on the evidence above, it can be strengthen the statement of the existence of the relationship between market orientation and innovation in the organization.

\subsection{Innovation and Organizational Performance Relationship}

According to Damanpour and Evan (1984), the adoption of a new idea in an organization regardless of the time of its adoption in the related organizational population is expected to result in an organizational change that might affect the performance of that organization. They further added that, the management's decision to adopt a new idea does not necessarily guarantee its implementation. Other requirements such as the acceptance of the new idea by organizational members or necessary modifications in the procedures must be satisfied. Damanpour, Szabat, and Evan (1989) attempted to investigate the relationship between administrative and technical innovations and organizational performance. They posited that organizations that have a high rate of adoption of both administrative and technical innovations would have higher performance level than those that have a low rate of adoption of both innovations.

In order to determine what research evidence presents for positive effects on competitiveness and profitability from the development of innovation, Read (2000) had quantitatively and qualitatively analyzed 20 research articles collected from relevant academic journals. From the study, he found that a positive relationship between an organization's innovativeness and its performance do exist.

\subsection{Market Orientation, Innovation and Organizational Performance Relationship}

Research made by Slater and Narver (1994) and Han et al., (1998) were among the first authors to suggest that innovation might be the missing link in the market orientation-performance relationship. The result of the study validated the previous studies (Slater \& Narver, 1994; Atuahene-Gima, 1996; Han et al., 1998; Hult, Hurley, \& Knight, 2004; Olavarrieta \& Friedman, 2008), on the role of innovation capability as an essential component in translating market orientation into business performance (Huhtala et al., 2010). Han et al., (1998) empirically test the postulated "market orientation-innovation-performance" chain whereby they empirically test and validate the mediating effect of innovation in the market orientation-corporate performance relationship at the bank sector and they found that the research fully supported the proposition of market orientation mediated by innovation will create superior performance. Additionally, the dimension of market orientation was analyzed individually on the relationship with innovation. Among all three components, customer orientation was found to be the dominant factor where the main effect of customer orientation was highly significant on organizational innovativeness whereas the other two did not approach the level of significance.

Using a component-wise approach, Cheng and Krumwiede (2010) examined mechanism whereby customer and competitor orientations contribute to new service performance by mediating effect of radical and incremental innovations. The study found a significant positive relationship between customer orientation and incremental service innovation, which leads to performance improvement. In the other hand, impact of competitor orientation upon market performance was fully mediated by radical service innovation. Even though different components stimulated by different types of innovation, in general, it is empirically discovered that innovation by itself mediated the market orientation and performance relationship.

\section{Proposed Conceptual Framework}

This study is to examine the relationship between market orientation, innovation and Takaful performance in Malaysia. The framework of the proposed conceptual model is shown in (Figure 1). 


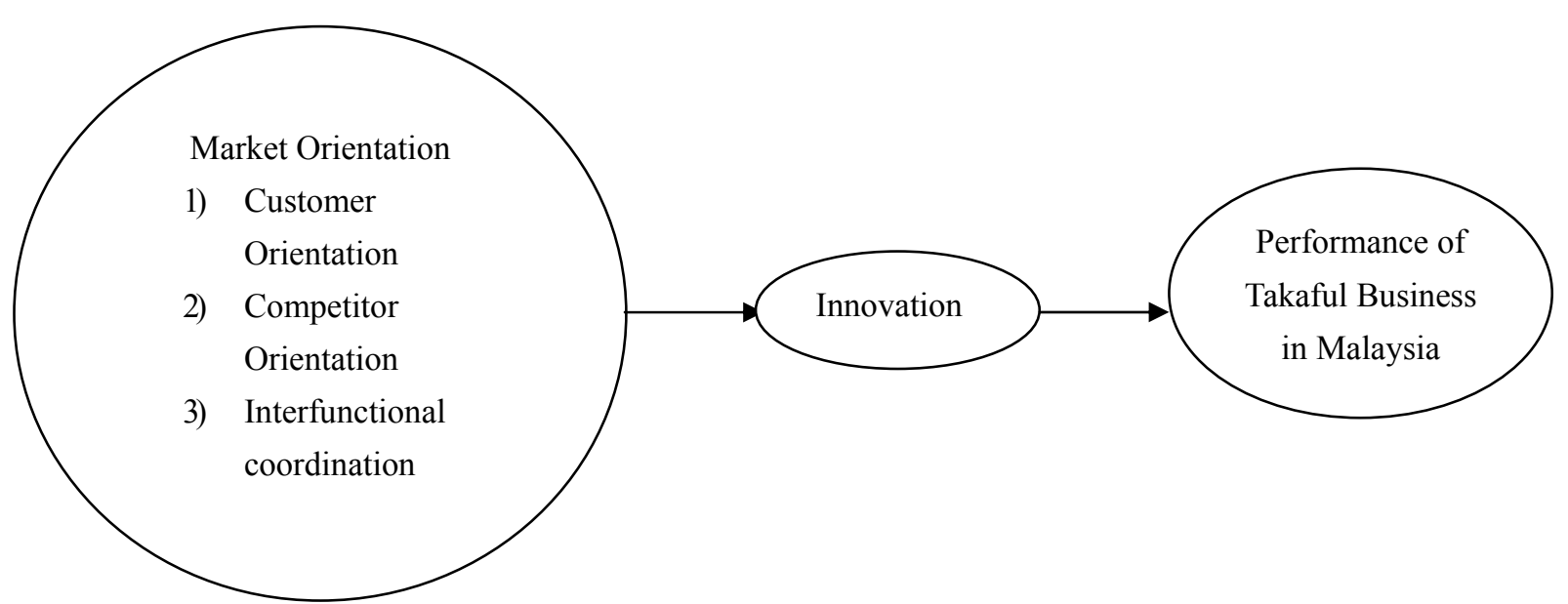

Figure 1. Conceptual framework of the relationship between performance and market orientation mediated by innovation

The following hypotheses are formulated based on the review of literatures. We hypothesized that:

H1a: there is a positive relationship between customer orientation and performance of Takaful business in Malaysia.

$\mathrm{H} 1 \mathrm{~b}$ : there is a positive relationship between competitor orientation and performance of Takaful business in Malaysia.

H1c: there is a positive relationship between inter-functional coordination and performance of Takaful business in Malaysia.

H2a: there is a positive relationship between customer orientation and innovation.

$\mathrm{H} 2 \mathrm{~b}$ : there is a positive relationship between competitor orientation and innovation.

$\mathrm{H} 2 \mathrm{c}$ : there is a positive relationship between inter-functional coordination and innovation.

H3: there is a positive relationship between innovation and performance of Takaful business in Malaysia.

H4a: there is a positive relationship between customer orientation, innovation and performance of Takaful business in Malaysia.

$\mathrm{H} 4 \mathrm{~b}$ : there is a positive relationship between competitor orientation, innovation and performance of Takaful business in Malaysia.

$\mathrm{H} 4 \mathrm{c}$ : there is a positive relationship between inter-functional coordination, innovation and performance of Takaful business in Malaysia.

\section{Methodology}

The research design will be a primary data where structured questionnaires will be asked to respondents. The target population of this research is the Composite Takaful Operator in Malaysia and the unit of analysis of this study is defined as Marketing Department in the Headquarters of six (6) Composite Takaful Operators in Malaysia licensed by Bank Negara Malaysia. The library search for books and online databases will also be optimized.

For the purpose of this study, the questionnaires consisted of four sections. Section A will be measuring the organizational Performance of the Takaful operators in Malaysia. Section B will be measuring the Market Orientation components; Customer Orientation, Competitor Orientation and Inter-functional Coordination. Section C will be measuring the Innovation of the Takaful operators in Malaysia. Section D will collect data on the demographic profile of the respondents and their firms or organizations. Five main statistical techniques are to be undertaken, namely factor analysis, reliability analysis, correlation analysis, descriptive analysis and regression analysis. 


\section{Conclusion}

The study attempts to examine the relationship between market orientation, innovation and Takaful performance. Findings of this study will be useful to managers and decision making levels of Takaful Operators to enhance and upgrade their marketing strategy by gaining superior performance and increase the penetration of Takaful market in Malaysia. This study expects a positive relationship between Market Orientation, innovation and performance of Takaful business in Malaysia. This study also expects innovation will mediate the relationship between Market orientation and performance of Takaful business in Malaysia.

\section{Acknowledgements}

The authors would like to convey special thanks to our sponsor, University of Sultan Zainal Abidin, Kuala Terengganu for providing the financial grant to this research.

\section{References}

Alchian, A., \& Demsetz, H. (1972). Production, information costs and economic organization. The American Economic Review, 777-795. http://dx.doi.org/10.2307/1815199

Atuahene-Gima, K. (1996). Market orientation and innovation. Journal of Business Research, 35, 93-103. http://dx.doi.org/10.1016/0148-2963(95)00051-8

Cheng, C., \& Krumwiede, D. (2010). The effects of market orientation and service innovation on service industry performance: An empirical study. Operations Management Research, 3(3-4), 161-171. http://dx.doi.org/10.1007/s12063-010-0039-x

Damanpour, F., \& Evan, W. (1984). Organizational innovation and performance: The problem of “Organizational Lag”. Administrative Science Quarterly, 29, 392-409. http://www.jstor.org/stable/2393031

Damanpour, F., Szabat, K. A., \& Evan, W. M. (1989). The relationship between types of innovation and organizational performance. Journal of Management Studies, 26(6), 587-602. http://dx.doi.org/10.1111/j.1467-6486.1989.tb00746.x

Dawes, J. (2000). Market orientation and company profitability: Further evidence incorporating longitudinal data. Australian Journal of Management, 25(2), 173-199. http://dx.doi.org/10.1177/031289620002500204

Ellis, P. D. (2005). Market orientation and marketing practice in a developing economy. European Journal of Marketing, 39(5/6), 629-645. http://dx.doi.org/10.1108/03090560510590746

Ellis, P. D. (2006). Market orientation and performance: A meta-analysis and cross-national comparisons. Journal of Management Studies, 43(5), 1089-1107. http://dx.doi.org/10.1111/j.1467-6486.2006.00630.x

Han, J. K., Kim, N., \& Srivastava, R. K. (1998). Market orientation and organizational performance: Is innovation the missing link? Journal of Marketing, 62, 30-45. http://dx.doi.org/ 10.2307/1252285

Homburg, C., Hoyer, W. D., \& Fassnacht, M. (2002). Service orientation of a retailer's business strategy: Dimensions, antecedents, and performance outcomes. Journal of Marketing, 66(October), 86-101. http://dx.doi.org/10.1509/jmkg.66.4.86.18511

Huhtala, J. P., Jaakkda, M., Frözĕn, J., Tikkanen, H., Aspara, J., \& Mattila, P. (2010, November-December). Market orientation, innovation capability and business performance: Insights from different phases of the business cycle. Paper presented at the ANZMAC Annual Conference, University of Canterbury.

Hult, G., T., Hurley, R., \& Knight, G., A. (2004). Innovativeness: Its antecedents and impact on business $\begin{array}{lllll}\text { performance. } & \text { Industrial } & \text { Marketing } & \text { Management, } & 33,\end{array}$ http://dx.doi.org/10.1016/j.indmarman.2003.08.015

Hult, G. T., \& Ketchen, D. J. Jr. (2001). Does market orientation matter? A test of the relationship between positional advantage and performance. Strategic Management Journal, 22(9), 899-906. http://dx.doi.org/10.1002/smj.197

Hunt, S. D., \& Morgan, R. M. (1995). The comparative advantage theory of competition. Journal of Marketing, 59, 1-15.

Hurley, R. F., \& Hult, G. T. (1998). Innovation, market orientation, and organizational learning: An integration and empirical examination. Journal of Marketing, 62, 42-54. http://dx.doi.org/10.2307/1251742

Im, S., \& Workman Jr. J. P. (2004). Market orientation, creativity, and new product performance in high technology firms. The Journal of Marketing, 68(2), 114-132. http://dx.doi.org/10.1509/jmkg.68.2.114.27788 
Kirca, A., Jayachandran, S., \& Bearden O. W. (2005). Market orientation: A meta-analytic review and assessment of its antecedents and impact on performance. Journal of Marketing, 69(2), $24-41$. http://dx.doi.org/10.1509/jmkg.69.2.24.60761

Kumar, K., Subramaniam, R., \& Yauger, C. (1998). Examining market orientation-performance relationship: A context-specific study. Journal of $201-233$. http://dx.doi.org/10.1177/014920639802400204

Lukas, B. A., \& Ferrel, O. C. (2000). The effect of market orientation on product innovation. Journal of Academy of Marketing Science, 28(2), 239-247. http://dx.doi.org/10.1177/0092070300282005

Olavarrieta, S., \& Friedman, R. (2008). Market orientation, knowledge-related resources and firm performance. Journal of Business Research, 61(6), 623-630.

Read, A. (2000). Determinants of successful organizational innovation: A review of current research. Journal of Management Practice, 3(1), 95-119.

Richard, P., Devinney, T., Yip, G., \& Johnson, G. (2009). Measurement organizational performance: Towards methodological best practice. Journal of Management 35, 718-804. http://dx.doi.org/10.1177/0149206308330560

Sany Sanuri Mohd, M., Rushami Zien, Y., \& Rozita, A. (2009). Market orientation critical success factors of Malaysian manufacturers and its impact on financial performance. International Journal of Marketing Studies, 1(1), 77-84.

Slater, F., \& Narver, C. (1994). Market orientation, customer value, and superior performance. Business Horizon, 22-28. http://dx.doi.org/10.1016/0007-6813(94)90029-9

Venkatraman, N., \& Ramanujam, V. (1986). On the measurement of business performance in strategy research: A comparisons of approaches. The Academy of Management Review, 11(4), 801-814. http://www.jstor.org/stable/258398 